\title{
An Extensive Review of Health and Economy of Bangladesh Amid Covid-19 Pandemic
}

\author{
Abdul Kader Mohiuddin ${ }^{1}$, Muhammad Ridwan ${ }^{2}$ \\ ${ }^{1}$ The Secretary and Treasurer of Dr. M. Nasirullah Memorial Trust, Tejgaon, Dhaka, Bangladesh \\ ${ }^{2}$ Universitas Islam Negeri Sumatera Utara, Medan, Indonesia \\ dr.m.nasirullah.trust@gmail.com; bukharyahmedal@gmail.com
}

\begin{abstract}
COVID-19 has affected 213 countries around the world, killing 711,313 and infecting around 19 million by August 06, 2020 (worldometer.info). Bangladesh, a South Asian lowmiddle-income economy, has experienced a demographic and epidemiological transition with rapid urbanization and a gradual increase in life expectancy. It is the seventh most populous country in the world and population of the country is expected to be nearly double by 2050. The increasing burden of communicable diseases in Bangladesh can be attributable to rapid urbanization and nearly $50 \%$ of all slum dwellers of the country live in Dhaka division. In 2017, National Rapid Response Team of IEDCR investigated 26 incidents of disease outbreak. Until August 6th, death reported 3,267 and 246,674 got infected in this country. The joint survey of the Power and Participation Research Centre and BRAC Institute of Governance and Development reveals that per capita daily income of urban slum and rural poor drops by $80 \%$ due to present countrywide shutdown enforced by the government to halt the spread of Covid-19. 40\%-50\% of these population took loans to meet the daily expenses. However, the country has just 127,000 hospital beds, 91,000 of them in government-run hospitals. Researchers say, the country's economy is losing BDT 33 billion every day from its service and agriculture sectors during the nationwide shutdown.
\end{abstract}

\section{Keywords}

domestic vidence during lockdown; healthcare denial; poor adherence to selfquarantine; natural Disasters amid Covid-19; repatriation of migrant workers, supply chain crisis

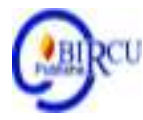

\section{Introduction}

Since the outbreak of Covid-19 (Corona virus) in China in December 2019, the disease has killed more people in Europa, America and Asia according to official sources (Modeawi et al, 2020; Ningrum et al, 2020; Bania et al, 2020). Notwithstanding the depressing state of major indicators such as negative export-import growth (FE Report, 2019a; FE Report, 2019b; Uddin, 2020a; Khatun, 2020); significant revenue drop (Byron, 2020; Parvez, 2020; The Financial Express, 2017; Senior Correspondent, 2019); shrinking private sector investment (Bhuiyan, 2019; Hasan, 2019a; Uddin, 2020b; TBS Report, 2019) ; rising un-performing loans documented in 2019 (Hasan, 2019b; Islam, 2019a; Islam, 2019b; Hasan, 2019c). Bangladesh's government was optimistic that somehow the depressing trend of these indicators might be reversed. But this optimism has now been seriously dented with the severe onslaught of Covid-19. The decline in national and global demand for manufactured goods, particularly in the garment sector, risks creating unemployment and deepen poverty. The urban poor will be hardest hit while the number of additional poor will be higher in rural areas. The IEDCR was Bangladesh's only Institute 
Konfrontasi Journal: Culture, Economy and Social Changes, 7 (3) September 2020, 168-183 ISSN: 1410-881X (Print), 2716-2095 (Online)

\section{Abdul Kader Mohiuddin, Muhammad Ridwan: An Extensive Review of Health and Economy of Bangladesh Amid Covid-19 Pandemic}

DOI: https://doi.org/10.33258/konfrontasi2.v7i3.113

http://www.konfrontasi.net/index.php/konfrontasi2

with testing facilities for COVID-19 until March 26, when a second facility was granted testing rights. Centralized testing has not yet been able to respond effectively to the wave of suspected COVID-19 patients in these under-resourced public institutions. Amidst this global crisis, Bangladesh has been identified as one of the 25 most vulnerable countries to be affected by the fast-spreading virus (Tajmim, 2020a; Tribune Report, 2020). By 25. 04. 2020, it was confirmed in 63 out of 64 districts (Figure 1) (Dhar, 2020). The combined capacity of 19 corona testing laboratories is around 5,000 samples per day, but in the last few days, authorities have conducted only 2,100 tests (UNB News, 2020a; Sakib, 2020). Unwillingness of the authorities concerned and bureaucratic complexities have indicated that the availability of a kit delays the detection of the novel coronavirus infection. Moreover, the government in Bangladesh has not so far sought to proactively limit transmission from primary cases to community.

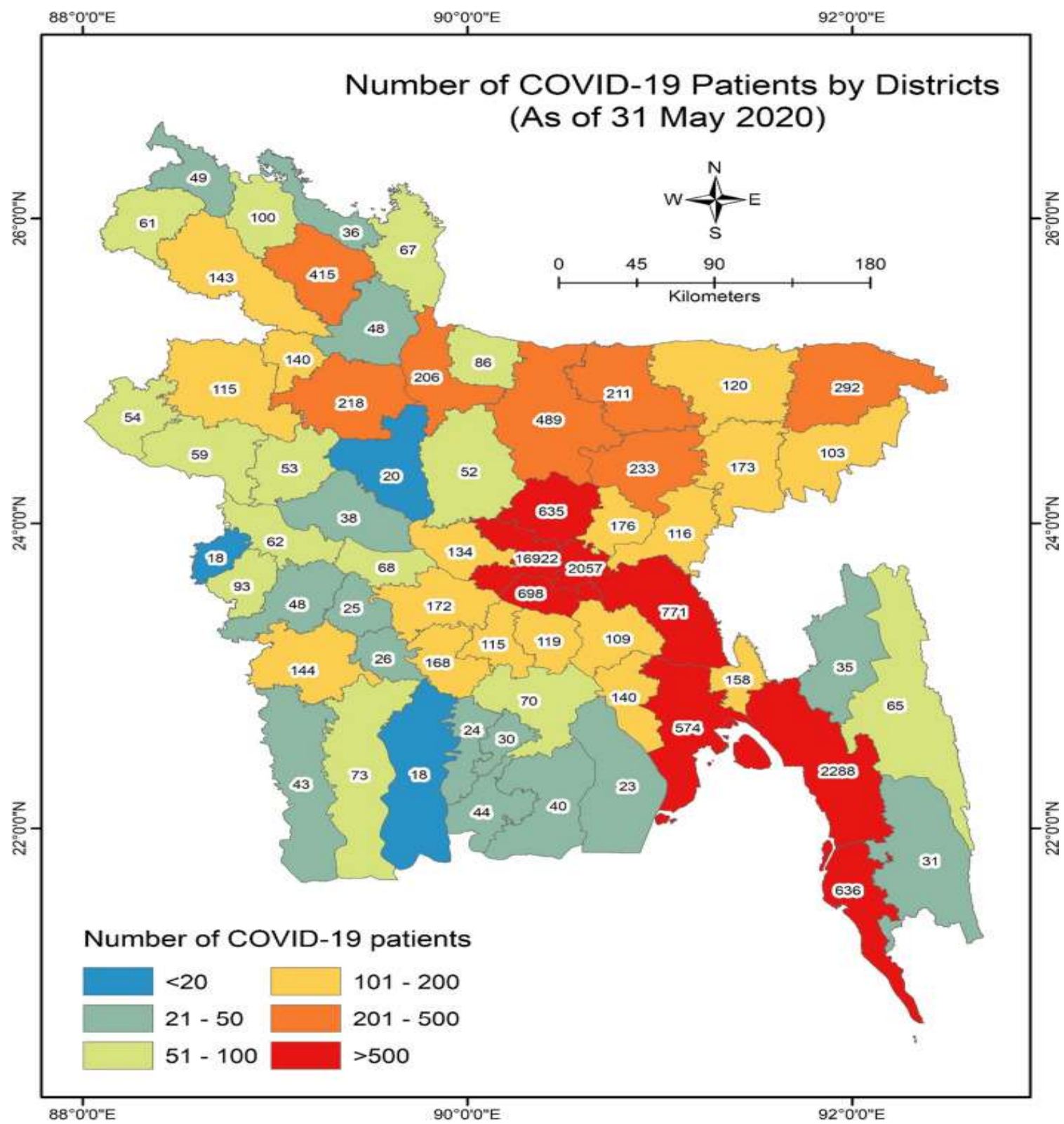

Figure 1. District wise COVID-19 Infected Cases in Bangladesh (As of 31 May, 2020)

(Shammi et al, 2020) 


\section{Review of Literatures}

\subsection{Current State of Epidemiology}

More than $80 \%$ of the 36751 coronavirus cases detected in Bangladesh have been reported in the Dhaka division and nearly $60 \%$ of them are in the capital, Dhaka (The Financial Express, 2020a; Noman, 2020a). Around 68\% of them are men while they comprise $73 \%$ of the dead, according IEDCR and experts are pointing 2 main reasons, outside exposure and hygiene practice (The Financial Express, 2020b). An analysis of the coronavirus patients by age demonstrated that the highest proportion of the infected people $24 \%$ - were between 31 and 40 years, followed by $22 \%$ in the age bracket of $21-30$ years and $16 \%$ aged 41 to 50 years, according to IEDCR (Figure 1). Virologists have noted a lack of testing that would give a clearer picture of the true number of coronavirus infections. As expected, Number of new infections raised after the country has softened its restrictions on factories to pave the way for reopening despite the worsening COVID-19 situation in the country (Figure 2) (Olukoga, 2020). Although, 8\% infected, no death was reported among the age bracket of 11 20 years (Figure 3 and 4 ).

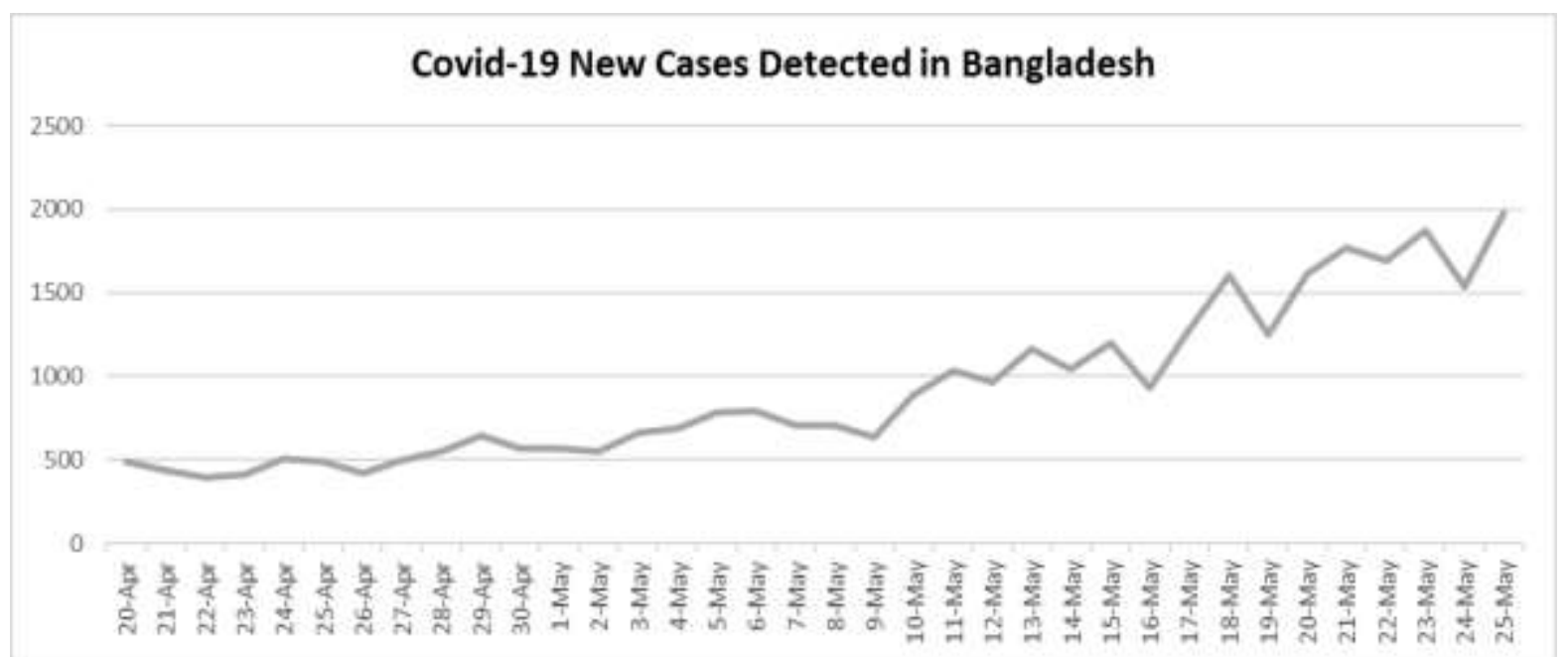

Figure 2. Covid-19 New Cases Detected in Bangladesh from 20-April to 15-May, 2020. The curve was almost flat. This means the infection rate was not increasing among lockdown. Practically, number of tests conducted so far is too small not truly represents the actual situation. However, the curve showing a significant turn after May-8, when the lockdown is partially withdrawn. 


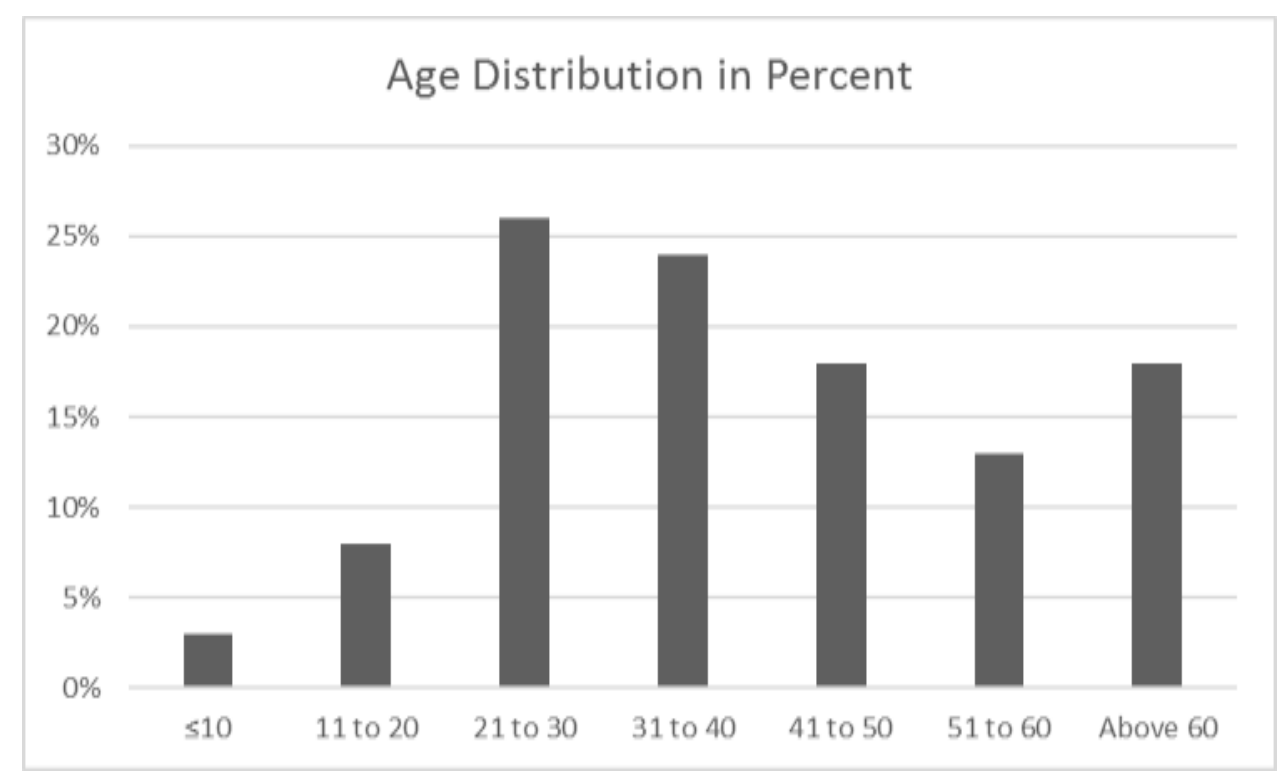

Figure 3. Age Distribution in Percent. Data from the Institute of Epidemiology, Disease Control and Research showed that $62 \%$ of the infected cases were aged between 1 and 50 years (Maswood, 2020).

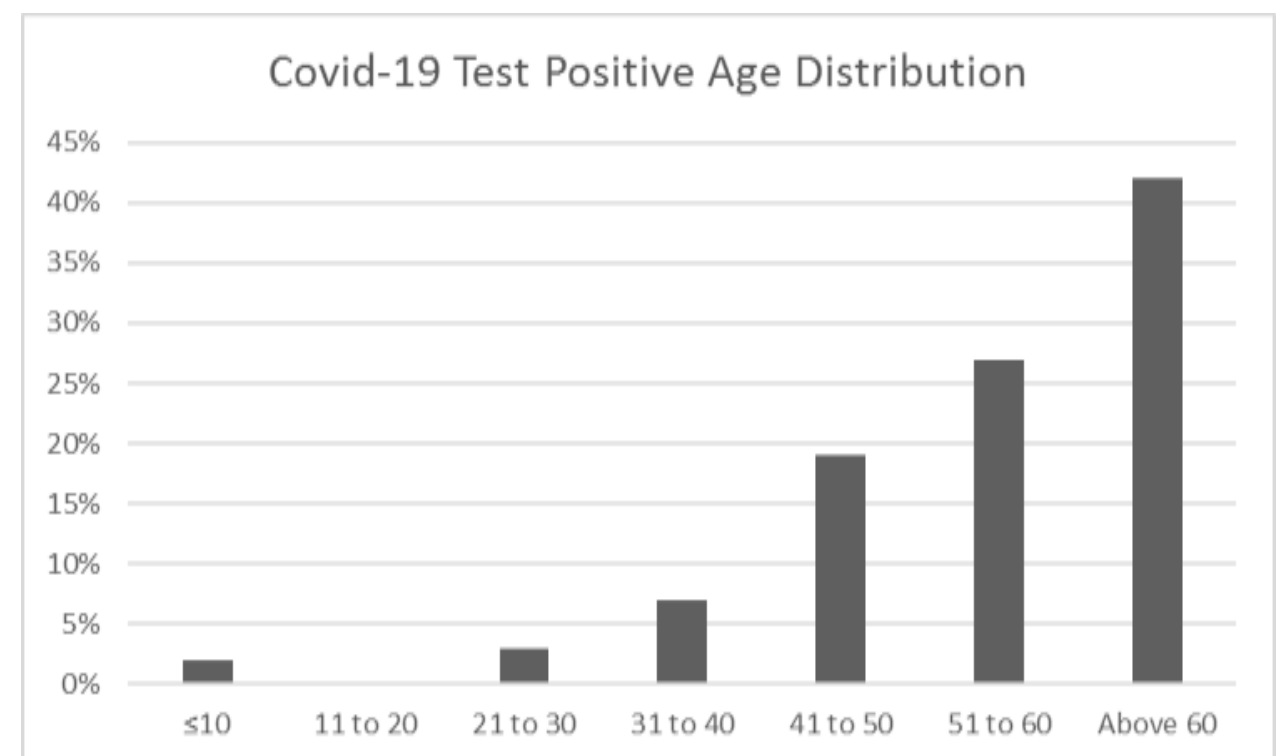

Figure 4. Covid-19 Test Positive Age Distribution Among Bangladeshi Population. According to IEDCR, highest death reported in patients above 60 and no death reported in the infected cases aged between 11 and 20 years.

\subsection{Present Hospital Situation with Covid-19 Patients}

Many patients with fever, cold and breathing problems-which are also COVID-19 symptoms-have gone untreated as the hospitals in Dhaka are sending them to the IEDCR for coronavirus test (Masum, 2020a). Most hospitals are not in a position to provide doctors and other health associates with the personal protective equipment (PPE) like masks, gloves, and infected patients could walk into the hospital at any moment (Ahmed et al, 2020a; The 
Financial Express, 2020c; Tithila, 2020; Adhikary et al, 2020; Star Online Report, 2020; Staff Correspondent, 2020a; Bosu, 2020). Many doctors are not providing services fearing the contagion and lab technicians are shunning workplaces, halting medical tests, according to the patients. In some cases, serious patients who are not affected by COVID-19, moved from one hospital to the other but could not receive treatment and finally died, the media reported. In another case, the doctor fled leaving the patient behind (Staff Correspondent, 2020b; Islam et al, 2020; Akhter, 2020; UNB News, 2020b). Doctors and other health professionals say they do not even have sufficient protective gear and the health care system cannot cope with the outbreak (Chowdhury, 2020a). Experts believe that older people afflicted with coronavirus need the most ICU support (Liu et al, 2020). The number of older persons in the country is over 0.8 million (Noman, 2020a). In line with international standards, a 100-bed hospital should have at least five ICUs (Tajmim, 2020b). In reality, hospitals in Bangladesh have less than 1200 ICU beds (432 govt, 737 private) in total against a population of 161.4 million people (Rungta et al, 2020). There are reportedly 1,769 ventilators in Bangladesh at this moment or in the pipeline, which means an average of one ventilator for every 93,273 people (Save the Children, 2020). Interestingly, Covid-19 is also producing large quantities of hazardous medical waste, with PPE used in hospitals being the main component (Razzak, 2020; Hossain, 2020).

\subsection{Public Awareness Vs Attitude}

Most people are now aware in Bangladesh that the disease can happen to anyone and even cause death (Hasan, 2020a). Although a nationwide BRAC survey (31 March-5 April 2020) says that almost 40 percent of respondents have no idea how to prevent the virus from becoming infected (Rahman, 2020). The shutdown, announced first on March 26, has already been extended fourth time to May 16th (BRAC, 2020; Opu, 2020). The government has discouraged movement after 6pm, instructing everyone to stay at home (Shawon et al, 2020). The people are fooling law enforcers by travelling from one district to another by mostly vehicles that transport goods (TBS Report, 2020a). Also, garment workers walk on the street demanding their due wages during the lockdown amid concerns over the outbreak in capital, Dhaka, on April 13, 2020 (Ahmed et al, 2020b; Reuters, 2020a). Surprisingly, around 100,000 people attended a funeral gathering for a popular Muslim cleric, ignoring calls from different quarters to maintain physical distancing and hygiene (Kamruzzaman, 2020; Mahmud, 2020a, Ramachandran 2020; Wyatt, 2020). Also, violence reported during this lockdown, where, 30 people were injured and one person's leg was cut off during the clash over establishing dominance (TBS Report, 2020b; TBS Report, 2020c; Staff Correspondent, 2020c). Several other violations are also reported like unnecessary public gathering, gossiping, roaming without a purpose, staring at home under lockdown etc. in both print and online media, inside and outside the capital (Chowdhury, 2020b; Chowdhury, 2020c; NEWAGE, 2020; Ramachandran 2020; Mahmud, 2020b; Editorial desk, 2020; Abdullah, 2020; Roy, 2020). Decision-makers say "Chinese lockdown strategy" will not be fully applicable to Bangladesh because of poor socio-economic conditions for people and other factors (such as government capacity, support infrastructure, technology and medical facilities). This risk is compounded by thousands of Bangladeshi workers returning from COVID-19-struck countries and poor adherence to self-quarantine recommendations due to limited education and monitoring mechanisms (Monjur et al, 2020; AFP Singapore, 2020; Uttom, 2020; TBS Report, 2020d). Although general holidays extended, the government has decided to allow businesspeople to keep shops and shopping malls open, considering 
Ramadan and Eid-ul-Fitr (The Financial Express, 2020d). The number of shops with less than 15 employees in the country is 5.6 million. Around 12 million employees work at those shops (Noman, 2020b). So, community transmission may not be fully protected. However, Government employees will not be allowed to leave their workplaces on the occasion of the 2020 Eid-ul-Fitr, one of the religious festivals for Muslims. And also, inter-district public transport will remain closed during the period, according to the order of the cabinet division (News Desk, 2020).

\subsection{Trial of Unlicensed Drugs and Unapproved Diagnostic Aids}

A group of Bangladeshi doctors of a private Bangladesh Medical College in Dhaka, claimed success after using Antiprotozoal medicine Ivermect in and Doxycycline antibiotic for coronavirus-19 infected patients (Staff Correspondent, 2020d; Masum, 2020c). Earlier, some other hospitals tried hydroxychloroquine, controversial for its life-threatening heart rhythm problems and hepatotoxicity (Tajmim, 2020c; Staff Correspondent, 2020e). some of the companies of Bangladesh has taken approval or started production of antiviral drugs like Favipiravir (Avigan ${ }^{\circledR}$, Japan) and Remdesivir and they are about to be used for the Covid-19 patients, although not authorized by WHO/FDA for the same (AFP Tokyo, 2020; TBS Report, 2020e; Reuters, 2020b). However, the government has issued a warning against using coronavirus antibody test kits without permission from the health authorities amid questions over the accuracy of results (Alif, 2020a; UNB News, 2020c).

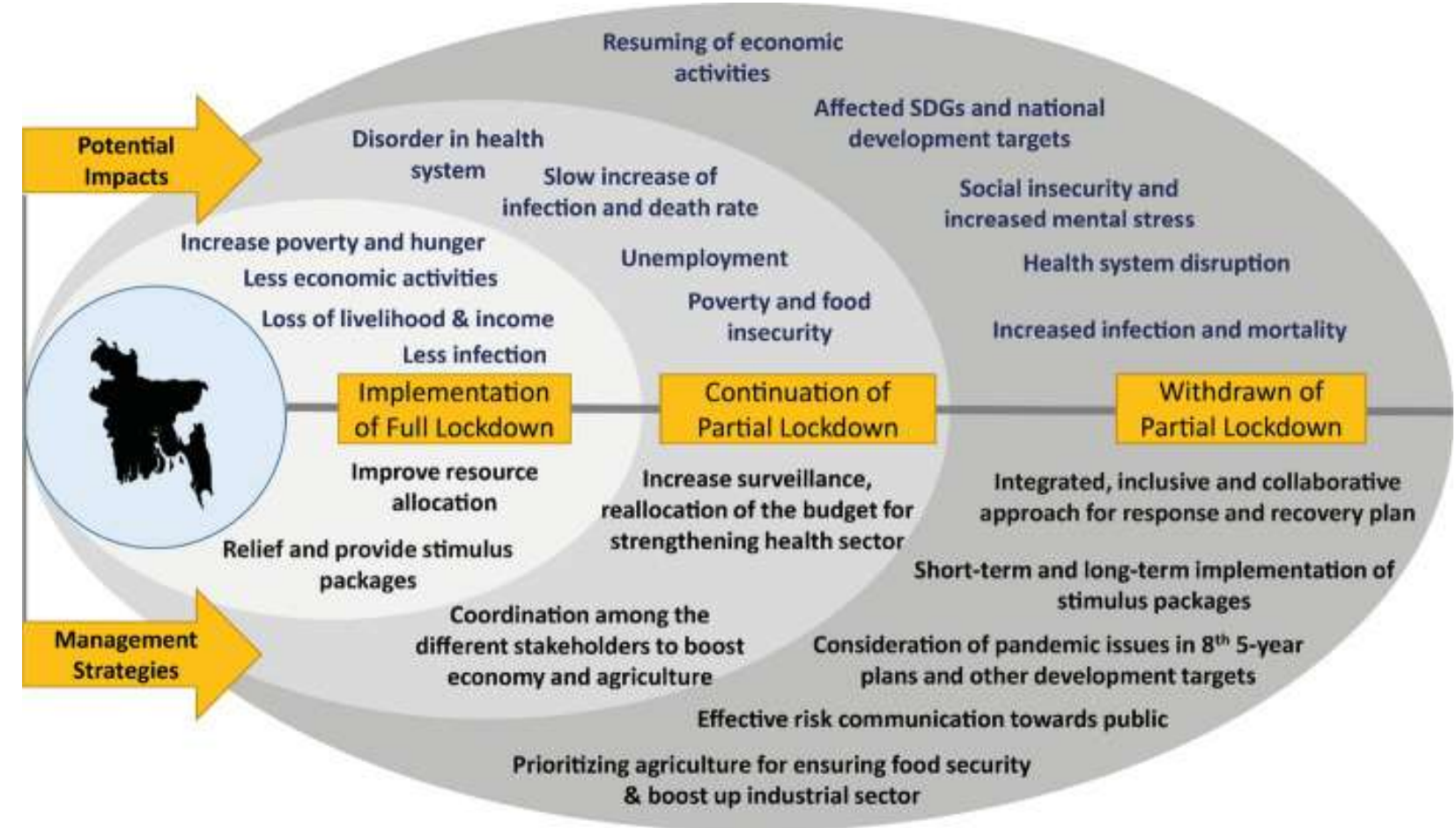

Figure 5. Comparative lockdown scenarios with impact and management analysis for Bangladesh due to COVID-19 pandemic 


\section{Discussion}

\subsection{Price Hike of the Daily Necessities and Natural Disasters amid Covid-19}

Where income of the poor dropped by $80 \%$, the prices of essential commodities surged, adding to buyers' woes amid the COVID-19 crisis between March and April, 2020 (Staff Reporter, 2020) (Figure 5). The suffering of some 7 million slum dwellers around Dhaka, is multiplying due to lost earnings and price hikes of consumer goods (Hasan, 2020b). Consumers alleged some unscrupulous traders have hiked the prices of commodities to make quick buck during Ramadan (The Financial Express, 2020e). After the first case of coronavirus was confirmed in Bangladesh the very next day the highest court of the country had to 'direct' the government to take necessary steps to stop price hike of masks, hand wash, and sanitizers, or storing them to make extra profits later (Saha, 2020). Nearly 35\% of the country's total import is China based and prices of various disposable medical instruments (bouffant caps, shoe cover, medical clothing, test strips, surgical gauze and sponges, surgical gloves, bed sheet, lab test instruments, and diagnostic reagents) have been showing an upward trend due to decline in their shipment (Bhuiyan, 2020). Although, Trading Corporation of Bangladesh launched open market sale of key essential items ahead of the fasting month of Ramadan, people queue/social distancing is rarely maintained there (TBS Report, 2020f; FE Report, 2020; Malay Mail, 2020). Syndicates are taking advantage of poor surveillance by government agencies to monitor prices. Increasing the demand for products which in turn is allowing many unscrupulous traders to increase prices two months ahead of Ramadan. This is increasing the scope for such traders to make more money through hoarding (Staff Correspondent, 2020f; Staff Correspondent, 2020g; Karim, 2020a). An opposite scenario is found with the farmers, as the prices of their produces have declined sharply for lack of marketing following the lockdown amid the outbreak (Mannan, 2020; Shuvo, 2019; Wardad, 2020; Mansur, 2020). A massive stream of desert locusts may be heading towards Bangladesh and India passing over the Indian Ocean. This possible attack from the crop destroying insects may worsen the situation further (Al Amin, 2020). Also, hailstorm, flood and other natural disasters are predicted for this year (Staff Correspondent, 2020h; Kelly, 2020). All these can multiply the severity of crisis in a near future.

\subsection{Economic Crisis Among Pandemic Situation}

$80 \%$ of the country's export earnings are from RMG sector and include $13 \%$ to the GDP of the country. The major export destinations include the United States, U.K., Germany, France, and Italy (Aslam, 2020; Kumar, 2020; Hossain, 2019; Munni, 2018). Pressure to meet production deadlines from American and European garment brands and possible loss of business to competitors have prompted factory owners to reopen manufacturing units (Aslam, 2020; Ellis-Petersen et al, 2020). These crowds could emerge new vectors of the COVID-19 pandemic in Bangladesh. Bangladesh has around 10.0 million workers overseas, with a majority in the Middle East and the US, UK, and Malaysia (Amit, 2020). However, most Bangladeshi migrants work in West Asia, where declining oil prices have hit economies. Many will be forced out of their jobs and will have to return home to unemployment (South Asia Economic Focus, 2020). This is not surprising because slowdown in US and EU economies have had ripple effects in the Bangladesh economy. The 'Centre for Global Workers' Rights' and 'Worker Rights Consortium' reported that international brands and retailers have suspended clothing orders from Bangladesh for up to $\$ 3$ billion (Kabir et al, 2020). Meanwhile, banks were trying to come to terms with the Ministry of Finance directive 
of $6 \%$ and $9 \%$ caps to interest rates on deposits and loans; vulnerable asset quality; moribund capital markets; and a struggling microfinance sector as access to donor funds and bank financing become more competitive (The Financial Express, 2020f; Hossin et al, 2020). It is worth noting that in the last three months, private sector credit growth was already declining. Banks were experiencing an additional pressure in paying clients as money withdrawal was more than any normal time, out of fear of lockdown (Hasan, 2020c). The central bank has taken several initiatives to meet the liquidity crisis in the banking sector and overcome the current economic crisis (Hasan, 2020d). However, Growth rate for Bangladesh, as projected by IMF, now stands at $2 \%$ for 2020 against $7.9 \%$ in 2019 (Mahmood, 2020). Also, The GDP is expected to grow by $8 \%$ in FY2021, according to the ADB (The Financial Express, 2020g). 57,500 tons of fresh fruits, 1,473 tons of onions, 475 tons of ginger, and 850 tons of garlic in 2,500 containers - have remained stuck at the Chittagong Port yard till April 25, due to the slow delivery of goods amid the Covid-19 shutdown (Chowdhury, 2020d; Karim, 2020b). Activities at Chittagong port have come to a standstill as the amount of import containers has exceeded the port's storage capacity due to slow delivery of goods. It may keep the ships waiting and it will increase the demurrage for importers. The number of containers at the port yard is increasing significantly since the importers are taking delivery of containers slowly as the country is going through lockdown (Hussain, 2020; The Financial Express, 2020h; TBS Report, 2020g). As sales of fresh fruits decreased, importers are not releasing their consignments from the port causing huge congestion of freezer containers in the port (Rahman, 2020). Product delivery from the port has declined due to the shortage of transport workers and vehicles, as well as slow revenue collection. Several importers expressed that they had brought in products amid a number of difficulties, but they were unable to receive deliveries due to the pandemic (Chowdhury, 2020e). However, the CPA is trying to transfer some containers to privately-run Inland Container Depots (ICDs) known as "Off-dock" as an alternative measure to tackle the situation.

\subsection{Rising Domestic Violence and Psychiatric Illness}

Millions around the globe are stressed and nervous due to various associated reasons such as-- fear of being infected and losing loved ones, losing livelihoods, job insecurity, feelings of helplessness etc. Social distancing can cause long-term stress, anxiety, insecurity, low self-esteem, negativity, frustration and low motivation and overall downfall of mental health, which could become the main cause for physical illness (Shah, 2020; Riyasad, 2020). Violence against women and children is on the rise in Bangladesh amid the COVID-19 lockdown due to lack of social activities and financial pressures are increasing rifts within families (Jahid, 2020; Hasan, 2020e; Asha, 2020). Violence against women is common in this country, especially against women who come from the impecunious sections of society. Rights activists say the lockdown has made women and children more vulnerable to domestic violence and abuse as many of them are confined to their homes with no outside support. According to a recent survey more than 4,700 women and 450 children were subjected to domestic violence in 27 out of 64 districts of Bangladesh in April, with more than 1,600 women and 420 children facing violence for the first time in their lives. More than $90 \%$ of the child victims were abused by their parents and relatives (Alif, 2020b; Welle, 2020; BRAC Institute of Governance \& Development, 2020; TBS Report, 2020h). 


\subsection{Strategic Recommendation}

It was apparent that maintaining partial lockdown with business and economic activities with social distancing and public health guidelines is the best strategy to maintain (Figure 6). However, as the government withdrew the partial lockdown, inclusive and transparent risk communication towards the public should be followed. However, experts suggested following measures:

a. During epidemic outbreaks, home care is particularly effective when health authorities are not safe to implement social distance systems and hospitals.

b. The National Disaster Council, under the leadership of Hon'ble Prime Minister, was formed on an urgent basis. As much work as it has been, the time has come to fold that whole work, to make it more integrated.

c. The awareness campaigns should be relentlessly conducted by the government, private organizations and the media to involve community participation with mutual distancing to be effective.

d. At less than 1\% of GDP, government health spending in Bangladesh is among the lowest in the world. The WHO recommends allocating at least 5\% of a country's GDP and $15 \%$ of the total budget for the health sector.

e. All government and private offices, educational institutions, garments, factories, except for the essential service providers, should be closed until the coronavirus infection is brought under control (Mohiuddin, 2020b).

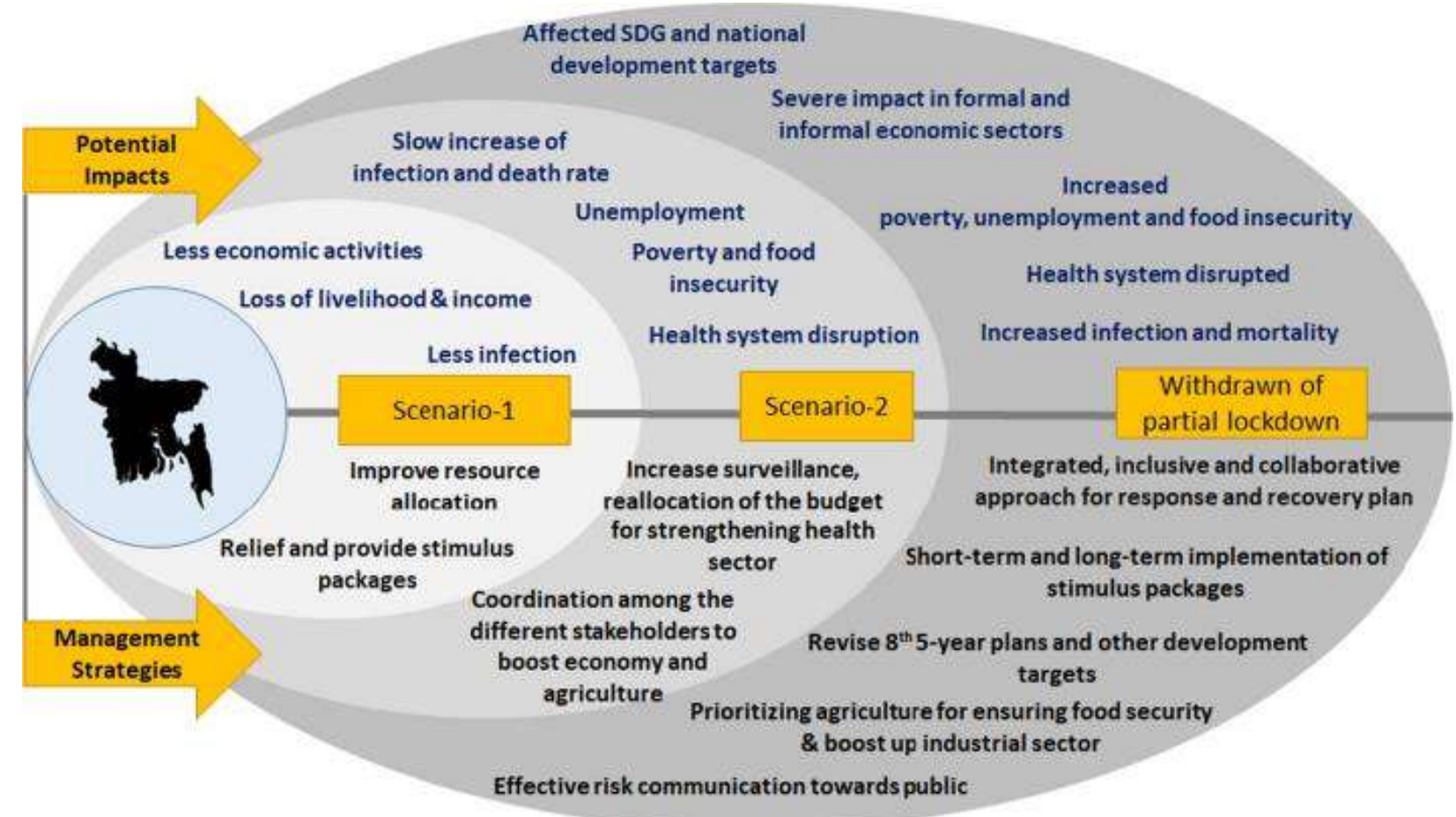

Figure 6. Possible management strategies and their respective impacts. 


\section{Conclusion}

Since there is no vaccine and specific anti-viral drugs so far, public health measures are considered as an effective tool to mitigate the impact of the virus in the community. The awareness campaigns should be relentlessly conducted by the government, private organizations and the media to involve community participation with mutual distancing to be effective. Telehealth can provide convenient access to routine care in a congested hospital or in medical practice without the risk of exposure. Government should spend additional resources directly on government doctors, drugs, hospitals and health centers and also increase the allocation in education to ensure quality by recruiting qualified teachers, retaining them by providing incentives and ensuring better infrastructural facilities and resources. Voice should be raised against domestic violence at the community level. Phased arrival of repatriated migrant workers will make things rather easy for the receiving authorities. At the end, The National Disaster Council, under the leadership of Hon'ble Prime Minister, should be more integrated. A collaboration between ministries is still a great concern.

\section{Abbreviations \\ IEDCR-Institute of Epidemiology, Disease Control and Research \\ BRAC-Bangladesh Rural Advancement Committee}

\section{Acknowledgement}

I'm thankful to Dr. Colin D. Rehm, Clinical Assistant Professor, Department of Epidemiology \& Population Health, Alert Einstein College of Medicine, NY, USA for her precious time to review my literature and thoughtful suggestions. Also, I'm also grateful to seminar library of Faculty of Pharmacy, University of Dhaka and BANSDOC Library, Bangladesh for providing me books, journal and newsletters.

\section{References}

Abdullah M. (2020). Coronavirus: Call for strict measures as people flout lockdown. DhakaTribune/Coronavirus, 17 April 17.

AFP Singapore. (2020). Bangladeshi workers live in fear as virus hits Singapore dorms. DhakaTribune/World, 09 April.

AFP Tokyo. (2020). Antiviral Avigan being tested for coronavirus patients. NEWAGE/Health, 17 April.

Ahmed I, Liton S. (2020a). Does Bangladesh have enough ventilators? The answer is no. The Business Standard, 31 March.

Ahmed S, Talukcar K. (2020b). Lax lockdown fails to contain coronavirus spread in Bangladesh. bdnews24.com, 02 May.

Adhikary TS, Islam R, Hasan R. (2020). Healthcare Professionals: On the front line, true to their oath. The Daily Star, 14 April.

Akhter F. (2020). COVID-19 and healthcare denial. NEWAGE OPINION, 02 April.

Al Amin M. (2020). Bad to worse: Looming locust attack amid coronavirus panic. DhakaTribune/Bangladesh, 27 April.

Alif A. (2020a). Rapid Test kits: Boon or bane? DhakaTribune/coronavirus, 09 April. 
Alif A. (2020b). MJF: 4,249 women subjected to domestic violence during the lockdown. 06 May.

Amit S. (2020). Coronavirus and the Bangladesh economy: Navigating the Black Swan event of 2020. DhakaTribune, 31 March.

Asha A. (2020). Violence against women continues unabated. The Independent/ Bangladesh, 08 March.

Aslam J. (2020). Bangladesh reopens 600 apparel factories despite virus risk. News4, 28 April.

Bania, A. S., Nuraini, N., \& Ulfa, M. (2020). Character and Student Ability of Covid-19 Understanding in Digital Era in 2020. Budapest International Research and Critics Institute (BIRCI-Journal) : $\quad$ Humanities, 3(3), 2233-2240. doi:https://doi.org/10.33258/birci.v3i3.1156

Bhuiyan AH. (2019). Flashback 2019 Economy: Falling exports, slow pvt credit major weaknesses. The Financial Express, December 31, 2019.

Bhuiyan AH. (2020). Coronavirus: Prices of disposable medical items rising. The Financial Express/Trade, 14 February.

BRAC, Bangladesh. (2020). Rapid Perception Survey on COVID19 Awareness and Economic Impact. 09 April. Available In: https://reliefweb.int/sites/reliefweb.int/files/resources/Perception-Survey-Covid19.pdf

BRAC Institute of Governance \& Development. (2020). Phase II Media Tracking of Domestic Violence, Bangladesh. Rapid Research Response to Covid-19, Series: Gender 03, 12 May. Available in: https://bigd.bracu.ac.bd/wp-content/uploads/2020/05/MediaTracking-of-DV_Phase-II.pdf

Bosu S. (2020). Doctors, caregivers unguarded for scanty protective gears. The independent/Bangladesh, 20 March.

Byron RK. (2019). Shrinking revenue: a growing worry. The Daily Star, 28 December.

Chowdhury T. (2020a). Poor Bangladeshis being turned away from hospitals. Al Jazeera America News/Bangladesh, 07 April.

Chowdhury Z. (2020b). City building 'locked down' in name, but not in reality. The Business Standard, 21 March.

Chowdhury Z. (2020c). Dhaka, Narayanganj clusters locked down. The Business Standard, 07 April.

Chowdhury SH. (2020d). 2,500 containers of Ramadan goods await delivery at Chattogram Port. The Business Standard/Trade, 28 April.

Chowdhury SH. (2020e). Supply disruption to push up prices of Ramadan essentials. The Business Standard/Markets, 13 April.

Dhar B. (2020). Coronavirus: Rangamati remains only district to report zero infection. DhakaTribune, 03 May.

Editorial Desk. (2020). Lockdown is a must to contain coronavirus. e-Prothom Alo, 08 April.

Ellis-Petersen H, Ahmed R. (2020). Bangladesh garment factories reopen despite coronavirus threat to workers. The Guardian/ Human rights in focus Bangladesh, 11 may.

FE Report. (2019a). ESCAP sees BD's positive trade growth in 2019. The Financial Express, 19 December.

FE Report. (2019b). Slower external trade may impact growth. The Financial Express, 30 December.

FE Report. (2020). TCB starts selling Ramadan essentials. The Financial Express/Trade, 28 April. 
Kelly M. (2020). Robust storms threaten flooding, strong winds over India and Bangladesh. AccuWeather/Severe Weather, 22 April.

Khatun F. (2020). Bangladesh Economy: Grappling with growing pains. The daily Star, 31 January.

Kumar A. (2020). Will the Pandemic Derail Bangladesh's Economic Growth? The Diplomet, 18 April.

Hasan M. (2019a). Private sector credit growth falls further owing to liquidity crisis. DhakaTribune/Business, 09 May.

Hasan M. (2019b). NPLs rise by Tk3863 crore in 3 months. DhakaTribune/Business, 28 November.

Hasan M. (2019c). Looking back 2019: Nothing tames bad loans. DhakaTribune/Business, 29 December.

Hasan K. (2020a). Healthcare professionals now face the coronavirus wrath. DhakaTribune, 29 March.

Hasan MR. (2020b). Amid Covid-19 Hunger Fear Mounts in Bangladesh. Inter Press Service, 29 April.

Hasan S. (2020c). Coronavirus: Banks under pressure to pay clients. UNB, 22 March 22.

Hasan M. (2020d). Bailout package: Banks' liquidity crisis to hinder implementation. DhakaTribune, 06 April.

Hasan F. (2020e). Addressing the rise in domestic violence during lockdown. The Daily Star, 20 April.

Hussain A. (2020). Delivery on limited scale may trigger container congestion at Chittagong port. DhakaTribune, 30 March.

Hossain, M. A. (2019). The Procedure of Cash Incentive and Its Role in the RMG Sector in Bangladesh: Evidence from Bangladesh. SSRN Electronic Journal. doi: 10.2139/ssrn.3334383

Hossain I. (2020). Amid COVID-19 pandemic, biomedical waste turning more hazardous. UNB News, 10 April.

Hossin, M. S., \& Rahman, M. A. (2020). Interest Rate Risk Management in Public Sector Bank of Bangladesh: With Special Reference to Sonali Bank Limited. Journal of Management, Economics, and Industrial Organization, 01-21. doi: 10.31039/jomeino.2020.4.1.1

IEDCR. (2020). COVID-19 Confirmed cases in Bangladesh (up to May 25, 2020). Available in:https://www.iedcr.gov.bd/website/images/files/nCoV/Case_dist_25_May_upload.pdf

Islam S. (2019a). Volume of NPL up 24pc in Q3. The Financial Express, 28 November.

Islam S. (2019b). NPL volume swells to Tk 939.11 billion. The Financial Express, 27 February.

Islam Z, Mollah S. (2020). Admission to Hospitals: Patients left in quandary. The Daily Star, 24 March.

Jahid A. (2020). COVID-19 and domestic violence. NEWAGE/Opinion, 23 April.

Kabir, H., Maple, M., \& Usher, K. (2020). The impact of COVID-19 on Bangladeshi readymade garment (RMG) workers. Journal of public health (Oxford, England), fdaa126. Advance online publication. https://doi.org/10.1093/pubmed/fdaa126

Kamruzzaman M. (2020). Bangladesh: Massive funeral for cleric amid lockdown. Anadolu Agency/World, Asia - Pacific, 18 April.

Karim R. (2020a). Intel agency warns against Ramadan price hike. The Financial Express/Trade, 10 February. 
Karim N. (2020b). It is imperative to ease port congestions for smooth trade. The daily Observer/OP-ED, 05 May.

Liu, K., Chen, Y., Lin, R., \& Han, K. (2020). Clinical features of COVID-19 in elderly patients: A comparison with young and middle-aged patients. Journal of Infection. doi: 10.1016/j.jinf.2020.03.005

Mahmud A, Garcia J. (2020a). 100,000 people gather for funeral in Bangladesh, defying coronavirus lockdown. cnn.com, 19 April.

Mahmud I, Rashid M. (2020b). Infection keeps rising in Bangladesh as people defy lockdown rules. NEWAGE/ Bangladesh, 25 April.

Mahmood M. (2020). The global economy in 2020: Grim outlook. The Financial Express/Views, 18 April.

Malay Mail. (2020). Bangladesh shuts down villages after tens of thousands attend cleric's funeral. World, 20 April.

Mannan MA. (2020). Coronavirus: Jashore farmers take the hit for falling vegetable prices. UNB/Special, 04 April.

Mansur AH. (2020). Taming coronavirus rampage: Ensuring food security during pandemic. The Daily Star/Business, 20 April.

Maswood MH. (2020). Young, working-age people mostly infected with COVID-19 in Bangladesh. NEWAGE/ Bangladesh, 13 April.

Masum O. (2020a). Dhaka hospitals turning away patients with fever, cold needing coronavirus tests. bdnews24.com, 19 March.

Masum O. (2020c). Does ivermectin work against COVID-19? Some say yes. bdnews24.com, 16 May.

Modeawi, M. N., Djoza, R. D., \& Ashande, C. M. (2020). Congolese Medicinal Plant biodiversity as Source of AntiCOVID-19 Compounds: Economic goods in the light of Comparative Advantages Theory of Ricardo. Budapest International Research in Exact Sciences (BirEx) Journal, 2(3), 298-309. doi:https://doi.org/10.33258/birex.v2i3.1067

Mohiuddin, A. K. (2020a). Covid-19 Situation in Bangladesh. doi: 10.20944/preprints202005.0094.v1

Mohiuddin, A. K. (2020b). COVID-19 and 20 Resolutions for Bangladesh. European Journal of Sustainable Development Research, 4(4). doi:10.29333/ejosdr/8433

Monjur, M., \& Hassan, M. (2020). Early phases of COVID-19 management in a low-income country: Bangladesh. Infection Control \& Hospital Epidemiology, 1-1. doi:10.1017/ice.2020.14.

Munni M. (2018). Germany now top export destination of BD garments. The Financial Express, 06 July.

NEWAGE. (2020). Narayanganj lockdown not fully implemented. Bangladesh, 12 April.

News Desk. (2020). Govt employees cannot leave workplace during Eid holiday. risingbd.com, 04 May.

Ningrum, P. A., Hukom, A., \& Adiwijaya, S. (2020). The Potential of Poverty in the City of Palangka Raya: Study SMIs Affected Pandemic Covid 19. Budapest International Research and Critics Institute (BIRCI-Journal) : Humanities, 3(3), 1626-1634. doi:https://doi.org/10.33258/birci.v3i3.1094

Noman M. (2020a). Half the country's Covid-19 infection in Dhaka city alone. The Business Standard, 11 May.

Noman M. (2020b). Covid-19 fallout: 56 lakh shop owners feel the pinch. The business Standard/ Covid-19 in Bangladesh, 29 April. 
Opu MH. (2020). In Pictures: The effects of coronavirus lockdown in Bangladesh. Aljazeera, 13 April.

Olukoga O. (2020). Bangladesh extends COVID-19 lockdown, softens restrictions for factories. NNN News Nigeria, 23 April.

Parvez S. (2020). Revenue shortfall can't stop stretching. The daily Star, 12 February.

Rahman, M. R. (2020). Real Action Needed To Prevent Corona: Bangladesh Perspective. Bangladesh Journal of Infectious Diseases. doi: 10.3329/bjid.v7i0.46794.

Rahman S, Illius S. (2020). Supply chain at risk. The Business standard/Trade, 19 April.

Ramachandran S. (2020). The COVID-19 Catastrophe in Bangladesh. The diplomat/South Asia, 29 April.

Razzak MA. (2020). Can Bangladesh cope with covid-19 medical waste? The daily Star/Opinion, 28 April.

Reuters, Dhaka. (2020a). Bangladesh textile wage protest. The Telegraph, India/World, 27 April.

Reuters. (2020b). Bangladesh's Beximco to begin producing experimental COVID-19 drug remdesivir. Bdnews24.com/Business, 05 May.

Roy R. (2020). Covid-19: National lockdown won't work alone. The Financial Express/Views, 29 March.

Rungta, N., Zirpe, K. G., Dixit, S. B., Mehta, Y., Chaudhry, D., Govil, D., Mishra, R. C., Sharma, J., Amin, P., Rao, B. K., Khilnani, G. C., Mittal, K., Bhattacharya, P. K., Baronia, A. K., Javeri, Y., Myatra, S. N., Rungta, N., Tyagi, R., Dhanuka, S., Mishra, M., ... Samavedam, S. (2020). Indian Society of Critical Care Medicine Experts Committee Consensus Statement on ICU Planning and Designing, 2020. Indian journal of critical care medicine : peer-reviewed, official publication of Indian Society of Critical Care Medicine, 24(Suppl 1), S43-S60. https://doi.org/10.5005/jp-journals10071-G23185

Riyasad N. (2020). COVID-19 and mental health around the world. NEWAGE/Youth, 26 April.

Sakib SMN. (2020). Bangladesh: Low COVID-19 testing rate raises concerns.

Saha KK. (2020). Pandemic coronavirus and price hike in medical items. The Asian Age/Editorial, 14 March.

Save the Children. (2020). COVID-19: Bangladesh has less than 2,000 ventilators serving a population of $165 \mathrm{~m}$, warns Save the Children. Press Release, 06 April.

Senior Correspondent. (2019). Bangladesh revenue growth slows to five-year low of $10.7 \mathrm{pc}$. bdnews24.com, 01 August.

Shah P. (2020). Psychological well-being: A challenge in Covid-19 regime. The Financial Express/Views, 06 April.

Shawon AA, Mamun S. (2020). Bangladesh likely to extend shutdown till May 16. DhakaTribune, 02 May.

Shammi, M., Bodrud-Doza, M., Islam, A., \& Rahman, M. M. (2020). Strategic assessment of COVID-19 pandemic in Bangladesh: comparative lockdown scenario analysis, public perception, and management for sustainability. Environment, Development and Sustainability, 1-44. Advance online publication. https://doi.org/10.1007/s10668-02000867-y

Shuvo M. (2019). Farmers lose, millers gain. The Daily Star, 28 May.

Star Online Report. (2020). Poor supply of PPE worries doctors. The daily Star, 20 March. 
Staff Correspondent. (2020a). Doctors, nurses and staff dangerously exposed. The Daily Star, 19 March.

Staff Correspondent. (2020b). Health minister vows to punish private hospitals for turning away patients. bdnews24.com, 03 April.

Staff Correspondent. (2020c). UP chairman among 2 held over rally with severed leg. The daily Observer/Countryside, 13 April.

Staff Correspondent. (2020d). Doctors claim success in corona treatment. The Daily Sun, 17 May.

Staff Correspondent. (2020e). No bar on export of hydroxychloroquine: commerce ministry. NEWAGE/Business, 20 April.

Staff Correspondent. (2020f). Government to monitor commodity costs to check price hikes. NEWAGE Bangladesh, 15 March.

Staff Correspondent. (2020g). Prices of Ramadan essentials rise. NEWAGE Business, 24 April.

Staff Correspondent. (2020h). '4 more disasters this month'. Daily Bangladesh/National, 04 May.

Staff Reporter, Dhaka. (2020). Daily essentials see price hikes amid COVID-19 lockdown. The Independent/ Business, 04 April.

South Asia Economic Focus, Spring 2020: The Cursed Blessing of Public Banks. (2020). doi: 10.1596/978-1-4648-1566-9

Tajmim T. (2020a). Covid-19 cases cross 200 since March, death toll hits 20. The Business Standard, 08 April.

Tajmim T. (2020b). Bangladesh has only 29 ICU beds to fight coronavirus! The Business standard, 24 March.

Tajmim T. (2020c). Bangladesh recommends controversial drugs for Covid-19 treatment. The Business Standard/Covid-19 in Bangladesh, 29 April.

Tithila KK. (2020). Coronavirus: Inadequate protective gear leaves Bangladesh health workers at high risk. DhakaTribune, 20 March.

TBS Report. (2019). 'The financial sector could be at risk of collapse'. The Business Standard/Banking, 28 November.

TBS Report. (2020a). General holidays likely to be further extended till May 16. The Business Standard/Covid-19 in Bangladesh, 02 May.

TBS Report. (2020b). Two groups clash in Brahmanbaria violating lockdown. The Business Standard, 12 April.

TBS Report. (2020c). Man, who lost leg during clash in Brahmanbaria, dies at DMCH. The Business Standard, 15 April.

TBS Report. (2020d). Bangladesh PM offers big aid for workers, poor over coronavirus. The business Standard/Bangladesh, 25 March.

TBS Report. (2020e). Bangladesh likely to start using Remdesivir by May 20, vaccine trial starts in June. The Business Standard/Health

TBS Report. (2020f). Buyers crowd TCB sales centres amid Covid-19 concerns. The Business Standard/Covid-19 in Bangladesh, 06 April.

TBS Report. (2020g). Coordination meeting held to mitigate container gridlock in Ctg port. The Business Standard/Trade, 14 April.

TBS Report. (2020h). 4700 women, children abused in families during April lockdown. The Business Standard/ Bangladesh, 06 May. 
The Financial Express. (2017). NBR tax revenue collection falls short of target. The Daily Star, 09 December.

The Financial Express. (2020a). BD records 1,166 new coronavirus cases, 21 more deaths. National, 26 May.

The Financial Express. (2020b). More men than women dying in BD from coronavirus. UNB/National, 18 April.

The Financial Express. (2020c). Most hospitals not in position to provide nurses PPE. UNB/National, 11 April.

The Financial Express. (2020d). Shops, shopping malls to remain open till 5 pm. National, 04 May.

The Financial Express. (2020e). Ginger, garlic witness abnormal price hike in capital. Trade, 25 April.

The Financial Express. (2020f). The challenge of executing single-digit interest rates. Views, 03 February.

The Financial Express. (2020g). BD economy expected to remain strong: ADB. Economy, 03 April.

The Financial Express. (2020h). Chittagong port should clear the gluts. Editorial, 15 April.

Tribune Report. (2020). US embassy: Bangladesh among 25 countries at risk of coronavirus. DhakaTribune, 04 March.

Uddin AKMZ. (2020a). Slowing exports stretching trade deficit. The Daily Star, 07 February.

Uddin AKMZ. (2020b). Why is private sector credit growth sinking? The Daily Star, 05 January.

UNB News. (2020a). 16 more testing labs soon: Health Minister. UNB, 10 May.

UNB News. (2020b). DU student 'denied treatment by hospitals' dies. The Financial Express/National, 07 April.

UNB News. (2020c). Unauthorised coronavirus testing kits can't be used: Ministry. UNB, 25 April.

Uttom S. (2020). Bangladesh asked to take back thousands of migrant workers. Union of Catholic Asian News/Bangladesh, 07 April.

Wardad Y. (2020). Farmers suffer for low demand, supply crunch. The Financial Express/Trade, 02 April.

Welle D. (2020). COVID-19 lockdown increases domestic violence in Bangladesh. taiwannews.com, 12 May.

Wyatt T. (2020). Coronavirus: More than 100,000 defy lockdown and gather for funeral in Bangladesh. 20 April. 